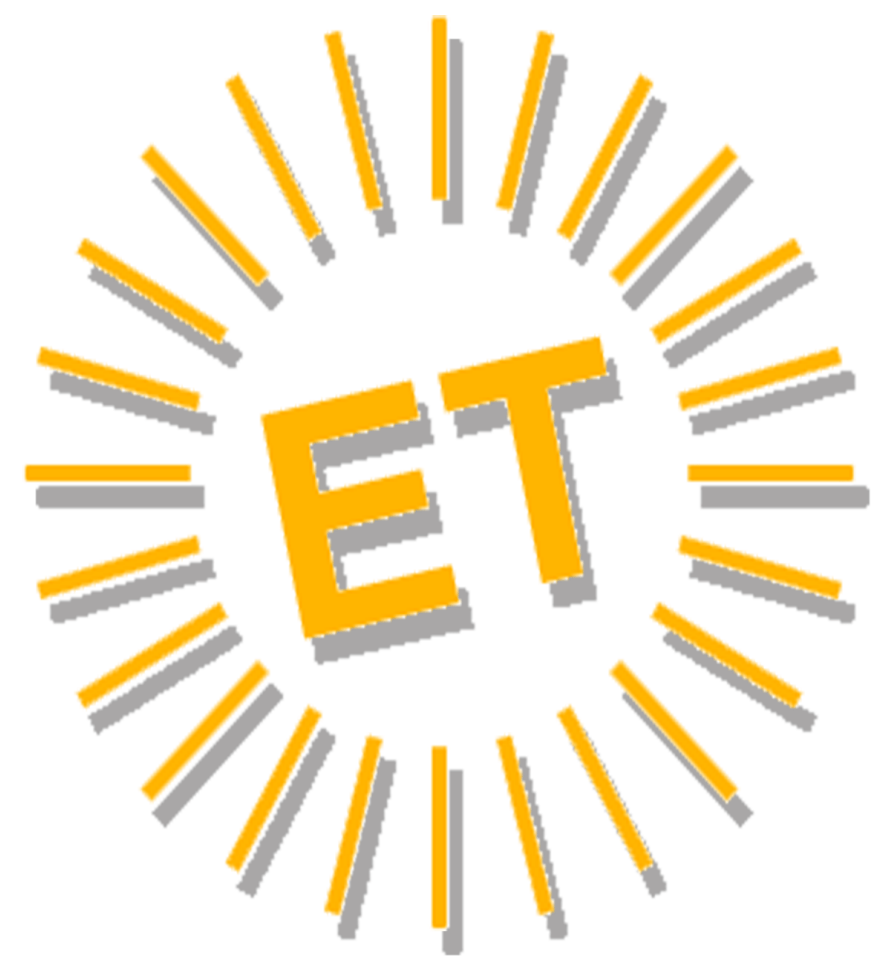




\section{Editorial Team}

\section{Editor in Chief}

Alfonso Vargas-Sánchez, University of Huelva, Spain

\section{Associate Editor}

Mirko Perano, Reald University College, Albania

\section{Books Review Editor}

Brendan Paddison, York St. John University, United Kingdom

\section{Secretariat}

Elena García de Soto, University of Huelva, Spain

Cinta Borrero-Domínguez, University of Huelva, Spain

\section{Style reviewer and text editor}

Anestis Fotiadis, I-SHOU University, Taiwan, Province of China

\section{Editorial Board}

José Manuel Alcaraz, Murdoch University, Australia Mario Castellanos-Verdugo, University of Seville, Spain José Antonio Fraiz-Brea, University of Vigo, Spain José Manuel Hernández-Mogollón, University of Extremadura, Spain

Tzung-Chen Huan, National Chiayi University, Taiwan, Province of China

Shaul Krakover, Ben Gurion University, Israel Jean Pierre Levy-Mangin, University of Quebec, Canada Tomás López-Guzmán, University of Córdoba, Spain Yasuo Ohe, Chiba University, Japón María de los Ángeles Plaza-Mejía, University of Huelva, Spain Nuria Porras-Bueno, University of Huelva, Spain João Albino Silva, Algarve University, Portugal

\section{Advisory Board (Spanish Members)}

Juan Manuel Berbel-Pineda, Pablo de Olavide University, Spain César Camisón-Zornoza, Uniersity of Valencia, Spain Enrique Claver-Cortés, University of Alicante, Spain María Teresa Fernández-Alles, University of Cádiz, Spain José Luis Galán-González, University of Seville, Spain Félix Grande-Torraleja, University of Jaén, Spain

Antonio Leal-Millán, University of Seville, Spain Inmaculada Martín-Rojo, University of Málaga, Spain Antonio Manuel Martínez-López, University of Huelva, Spain Francisco José Martínez-López, University of Huelva, Spain Pablo A. Muñoz-Gallego, University of Salamanca, Spain
Francisco Riquel-Ligero, University of Huelva, Spain José Miguel Rodríguez-Antón, Autonomous University of Madrid, Spain

Sandra Sanchez-Cañizares, University of Cordoba, Spain Josep Francesc Valls-Giménez, ESADE, Spain

\section{Advisory Board (Other European Members)}

Tindara Abbate, University of Messina, Italy Paulo Aguas, University of Algarve, Portugal Carlos Costa, Aveiro University, Portugal Dianne Dredge, Aalborg University, Denmark Salvatore Esposito de Falco, University of Rome "La Sapienza", Italy

Sheila Flanagan, Dublín Institute of Technology, Ireland Tania Gorcheva, Tsenov Academy of Economics, Bulgaria Tadeja Jere Jakulin, University of Primorska, Slovenia Metin Kozak, Mugla University, Turkey Álvaro Matias, Lusiada University, Portugal Alfonso Morvillo, National Research Council, Italy Alexandru Nedelea, Stefan cel Mare University of Suceava, Romania

Claudio Nigro, University of Foggia, Italy

Angelo Presenza, University "G. D'Annunzio" of Chieti-Pescara, Italy

Kanes Rajah, Royal Agricultural University, United Kingdom

\section{Advisory Board (Members from the rest of the world)}

John Allee, American University of Sharjah, United Arab Emirates

Nestor Pedro Braidot, National University of La Plata, Argentina

Roberto Elias Canese, Columbia University, Rector, Paraguay

Luca Casali, Queensland University of Technology, Australia Nimit Chowdhary, Indian Institute of Tourism and Travel Management, India

Steven Chung-chi Wu, National Pingtung University of Science and Technology, Taiwán

Dianne Dredge, Southern Cross University, Australia Daniel Fesenmaier, Temple University, United States

Babu George, Alaska Pacific University, United States Dogan Gursoy, Washington State University, United States Jafar Jafari, University of Wisconsin-Stout, United States Sanggun Lee, Pai Chai University, Korea Republic of Albert Yeh Shangpao, I-SHOU University, Taiwán Pauline Sheldon, University of Hawaii, United States Germán A. Sierra-Anaya, University of Cartagena de Indias, Rector, Colombia Xiaohua Yang, University of San Francisco, United States 


\title{
SHAPING THE FUTURE OF THE HOTEL SECTOR THROUGH CONSORTIA: THE PORTUGUESE CASE
}

\author{
Sofia Almeida \\ Universidade de Europeia (Portugal) \\ salmeida@universidadeeuropeia.pt
}

Carlos Costa

University of Aveiro (Portugal)

ccosta@ua.pt

José Manuel Simões

Universidade Lisboa (Portugal)

imsimoes@campus.ul.pt

Inês Carvalho

Universidade Europeia (Portugal)

ines.carvalho@universidadeeuropeia.pt

\begin{abstract}
Networks are cooperation arrangements that have gained importance over the last century. In the future, network-based and network structures will be among the most important organizational models. Therefore, this assumption formed the basis of the questionnaire designed for conducting this research. The objectives of this research are: (1) to examine hotel decision-makers' perceptions about the future of networks in tourism and (2) to analyse the influence of online distribution on hotel marketing consortia. A questionnaire was sent to four- and five-star hotel
\end{abstract}


units in Portugal. Quantitative and qualitative data analysis was performed. Main conclusions and recommendations for both academics and practitioners are then presented and discussed.

\section{KEYWORDS}

Network model, hotel marketing consortium, hotel sector, Portugal ECONLIT KEYS

L140; L220, Z310

\section{INTRODUCTION}

The tourism industry is composed of many interdependent services, which together facilitate tourists' destination experience (Buhalis, 2000) and also cocreation of experiences (Sfandla \& Björk, 2013).

As such, how these services interact and contribute to build a competitive value chain is crucial to the sustainable development of the tourism system, as well as to the individual businesses. Distribution systems are critical for industry competitiveness and this is even truer of the tourism industry, as many producers contribute to the quality of the overall tourism experience. Traditionally made of many layers and players in the distribution system, the tourism industry is currently facing great changes due to the dissemination of the digital paradigm. Consumers and producers are closer than ever before, and competition is continuously increasing due to the entrance of 'heavy weights' in the global market. Changes are shaping new roles, resources, and capacities for both parties. Today's business landscape is claiming for more competitive businesses and more integrated approaches to tourism development.

Networks are cooperation strategies adequate to respond to the current demands of competitive marketing environments and consumers. Baggio (2017), Tran, Jeeva \& Pourabedin (2016), Scott, Baggio \& Cooper (2008), Costa (1996) and Ōmae (1995) argue that, in the future, network-based businesses and network structures will be among the most important organizational models. Fyall \& Garrod (2005) also highlight the importance of networks for achieving competitive and sustainable objectives.

Literature suggests network arrangements will become the norm in the tourism landscape, in face of challenges ahead. These and similar claims are highly interesting and appealing, however there is little knowledge about the perspectives of practitioners, i.e. those dealing on a daily basis with major constraints and 
obstacles regarding the development of their business. Tourism competitiveness and sustainability depend highly on the ability to integrate the interests and needs of the various elements of the system.

Furthermore, the hotel sector is a key sub-sector of the tourism system, as no tourism is possible without catering for the needs of visitors for some sort of accommodation at the destination (Attila, 2016). However, the hotel sector is still an under-researched area of the tourism system, and many topics and issues need to be understood and addressed (Solnet, Paulsen \& Cooper, 2010). This research has been performed with the goal of uncovering hotel managers' perceptions about the future of this sector.

This article aims to shed light on how hotel managers regard the evolution of networks and marketing consortia, especially in a context of growing online distribution. Hence, the objectives of this research are: (1) to examine hotel decisionmakers' perceptions about the future of networks in tourism; and (2) to analyse the influence of online distribution on hotel marketing consortia. Such a study has not been carried out before. Contributions to theory as well as to practice expectedly may help the development of overall tourism but in particular the hotel sector, as competition is now as globalized and fierce as never before.

\section{LITERATURE REVIEW}

The theoretical background of this study is network theory and marketing theory, since the constructs used are mainly drawn from these two theoretical fields. The application of network theory in the field of tourism is recent. More specifically, networks have been approached in tourism research from the perspectives of planning (Breda et al., 2006; Costa et al., 2008; Scott, Cooper \& Baggio, 2008), innovation (Brandão, 2013), knowledge transfer (Baggio \& Cooper, 2008), destination promotion and management (Hall et al., 2014; Lynch \& Morrison, 2007; Grängsjö \& Gummesson, 2006; Karl \& Reintinger, 2017), small businesses (Breda et al. 2006), networks performance (Ramayah, Lee \& In, 2011), information and communication technologies (Morrison et al., 2004; Tran, Jeeva \& Pourabedin, 2016), and hotel chain management (Almeida et al. 2014, 2018; Litteljohn et al., 
1996). As to marketing theory, specific references are based on studies of hotel marketing consortia as communication and distribution channels (Ayazlar, 2016; Buttle, 1986; Byrne, 1993; Jafari, 2000; Kotler et al., 1996; Litteljohn, 1982; Roper, 1992; Slattery et al, 1985).

Imminent changes in the organizational landscape signal the need for a new generation of organizational theory that responds to the assumptions, aspirations, and adversities that characterize networks as organizational forms (Contractor et al., 2006). Although the interest in the study of organizations from a social networking perspective began in the 1960s, fundamental changes in the organizational landscape point to the need of evolving towards the study of networks in or between organizations.

\section{1) NETWORKS APLLIED TO BUSINESS ORGANIZATIONS}

In the business field, the concept of network is used in several contexts with different meanings, such as in the context of strategic alliances, joint ventures, leasing, consortia, social networks and business cooperation networks (Powell, 1990). Recently, the term network has also emerged associated with a new form of online communication, Web 2.0. (O'Reilly, 2005). Powell (1990) evoked the image of a network to refer to the links between individuals and organizations. Cooke and Morgan (1993) pinpointed that networks developed from the shortcomings associated with markets and vertical hierarchies, mainly due to changes of technology, the emergence of product innovation and changing market demand trends.

According to Child et al. (2005, p.147) companies seek to create or join existing networks, in order to obtain benefits such as: reducing the uncertainty of markets and transactions, as a network implies the creation of relationships based on trust and solidarity between members; flexibility in the production and distribution of resources; increasing speed by taking advantage of opportunities with immediate responses due to resource availability, capacity and flexibility.

In a hotel-based approach, according to Lynch (2000), hotel chains (networks) have been used by hotel companies to: i) reduce the effect of competition through price and rate fixing; ii) reduce dependence on the location of accommodation units 
where tourist flows are concentrated; iii) develop internal and external networks to gather information; and iv) reduce distances, since guests are treated as friends rather than customers paying for a service. Morrison (1994) suggests strategic alliances as an appropriate marketing management option for small businesses that do not dominate the market. Littleljohn et al. (1996) analysed accommodation consortia in Scotland and concluded that members were in favour of using networks for promotional purposes.

This research showed high levels of cooperation, but with limited effect on actual business performance. It is still difficult to establish relations between network activity, customers and company's performance.

\section{2) CONSORTIA AND DISTRIBUTION CHANNELS}

A hotel consortium is a network structure, 'a group of hospitality organizations that is allied for the mutual benefit for the members' (Kotler et al., 1996, p. 460). Properties in a consortium can be independently owned and managed, while gaining advantages of group marketing (Kotler et al., 1996). They may be simultaneously a communication channel and a distribution channel. Consortia are usually focused on the brand and reservation systems, besides providing advice and training. Some of the benefits of affiliation to consortia may be in terms of commercialization (Cushing, 2004), distribution (Holverson, Holverson \& Centeno, 2010) and increased sales.

Before the internet, it was critical for an independent hotel to join a consortium to obtain global bookings. The Internet has revolutionized traditional distribution models, allowed new entries, propelled both disintermediation and re-intermediation and transformed the sources of competitive advantage (Buhalis \& Kaldis, 2008). The reconfiguration of distribution channels has pushed simultaneous competition and cooperation between principals and intermediaries (O'Connor \& Frew, 2002). While some of the benefits provided by consortia have waned with the growth of online distribution, online distribution has also increased the bargaining power of consortia (Lee et al., 2013). Prior to the Internet, it was critical for an independent hotel to join a consortium for global bookings. Nonetheless, as Internet use increases in favour of unique hotel marketing, consortia continue to block a crucial role in threats from independent hotels (Cushing, 2004). 
There is a great discussion about hotel intermediaries, namely the possibility of their disappearance as a result of the new transformations in the market and the entry of new actors. By having fewer intermediaries, the gap between producers and customers is reduced. Blythe (2008, p. 643) stated that "slowing the path between producers and consumers, almost invariably reducing costs while increasing efficiency". This proximity allows small hotels to maintain their differentiation and independence and at the same time, helped by consortia brand, to become globally recognized. Also, marketing consortia, supported by technology, enable greater flexibility for each hotel member to select the personalized services they need (Cushing, 2004). According to Vallen \& Vallen (2009), independent hotels are at a disadvantage when fighting against the logos of large chains and against the reservations systems and their competitors. It is important to fight preconceived ideas of hotel directors, such as "If and when I become an affiliate" for another record: "How to choose the right organization?". Consortia are more flexible, focusing on brand and reservation systems, providing advice, consulting and training.

\section{3) THE SERVICES PROVIDED BY CONSORTIA}

Each consortium offers different levels of service and charges different annual marketing fees, in return for reaching the desired target audience by providing a marketing and sales structure. According to Quintas (2006), in addition to the sales component, marketing consortia provide (given their resources) the following services: advertising; public relations; direct mailing; participation in fairs and workshops; publishing and distributing manuals through member establishments.

They also deliver other services such as helping with specific problems (consultation), product analysis, market situation information or staff training programs. According to Walker and Walker (2013), consortium members share the Central Reservation System (CRS), benefit from a common image, have a logo and slogan, and in parallel, share discounts on bulk purchases and benefit from training management programs. Knowles (1996) refers to generic services as follows: existence of sales offices in major issuing regions; a website promoting branding for all members and booking hyperlinks for each member; a directory that lists all hotel 
members; a sales team that establishes relationships between travel agents and tour operators for the MICE (Meeting, Incentives, Congress and Exhibition) market; participation in international tourism fairs to consolidate the brand; liaison with global distribution systems (GDS); and creation of international contract opportunities with travel agencies.

According to the literature, there are several benefits for the independent hotels that choose to be part of marketing consortia (Bowie \& Buttle, 2013; Chon \& Yu, 2012; Holloway \& Plant, 1998; Holverson \& Revaz, 2006; Rowley \& Purcell, 2001; Litteljohn, 1982; Niewiadomski, 2014; Yeoman \& Beattie, 2006). These benefits are: i) increased visibility - members of a consortium are listed on a brand website and have access to the best conditions through GDS code; ii) building relationships with travel agencies - consortia provide specific opportunities between partners and travel agencies; iii) increased revenue through increased night sales and revenues through joint marketing efforts; iv) more marketing opportunities - as consortia allow for the possibility of competing with multinational companies in international markets and accessing global distribution systems; v) promotion support - consortia support all members attending national and international fairs; vi) cost reduction - for consortium members there is a cost reduction in bulk purchases, particularly purchases of food, beverages and cleaning supplies, to take advantage of economies of scale; vii) local needs - adapting to local hotel needs, such as managing periods of low demand, as well as overcapacity; viii) capturing niches to reach new consumers, due to the benefits of national and international branding, through joint presentations and use of the same CRS; ix) brand capital - enjoying the advantages of belonging to an international credible brand.

Despite the benefits, there are also limitations faced by consortia (Holverson \& Revaz, 2006; Gatsinzi \& Donaldson, 2010; Lazer \& Layton, 1999; Littlejohn, Holloway \& Plant, 1998; Morrison et al., 1994; Niewiadomski, 2016). These limitations are: i) the ability to offer different hotels with different shapes and sizes the opportunity to be a member can prove problematic for consortia that lack the ability to balance or promote each member equitably; ii) member hotels appearing in the same consortium but targeting different markets can be a source of dissatisfaction for end consumers; iii) different origin of consumers' motivations to travel and, therefore, it is difficult to improve the quality of service; iv) violation of 
norms can affect end consumers, a negative reference to a member negatively influences the whole consortium; v) legal issues, as common laws do not apply to all countries of the world; vi) repatriation of fees and different tax regulations, and finally vii) regional differences, unavailability of skilled work and lack of hotel schools can leverage symmetries between hotels poor infrastructure, inaccessibility to destination and difficulties in meeting customer needs. Local hotels are forced to implement the requirements of a consortium and this can become costly. For a small and independent hotel, being part of a network, such as hotel consortia marketing, presents some benefits, such as having short access to complex resources, but also limitations, such as losing their independence and the interdependence within these networks.

\section{METHODS}

This research presents partial results of a broader study on hotel marketing consortia. The partial results here presented and discussed are related with hotel managers' perceptions of the future role of consortia in hotel marketing. This study consisted of several stages. In the first stage, exploratory interviews were carried out with the CEO of a German consortium operating in Portugal, and with several sales \& marketing managers of independent hotels and hotels belonging both to small and large chains. This selection was justified by the need of collecting the opinions of decision-makers from different types of hotels. Together with the literature review, these interviews were the basis for designing the questionnaire. Afterwards, a pilot study was carried out in order to fine tune the questionnaire. Pilot study was done with 7 respondents in order to test the clarity of the language and the relevance of the questions. Once the pilot study was successfully completed, the final study was carried out.

The population chosen for this research concerns all four and five-star hotels in Portugal. A database of four and five-star hotels was compiled using several sources. Online questionnaires were then sent by email to the 688 hotels in the database, and managers were addressed to participate in the study. 327 hotels returned valid questionnaires (54\% response rate). Our study concerns two subsamples from this database. These sub-samples encompass the respondents who 
commented on two statements (S1 and S2) (see Table 1). The qualitative analysis of these comments is the main focus of analysis in the present study. These statements are optional. Respondents are not obliged to comment their answers.

\begin{tabular}{|c|c|c|c|}
\hline Hotels & 4 stars & 5 stars & Total \\
\hline Main sample & 240 & 87 & 327 \\
\hline Sub-sample for S1 & 78 & 37 & 115 \\
\hline Sub-sample for S2 & 56 & 22 & 78 \\
\hline
\end{tabular}

Table 1: Hotel types included in the study

Source: own elaboration

The main research question of this study is: how do hotel managers perceive the growth of networks and marketing consortia in the future? In order to answer this research question, respondents were asked to rate their level of agreement with the following statements:

(S1) It is likely that all hotels will be grouped together in networks in the future.

(S2) It is likely that the increase in online distribution will motivate the emergence of new marketing consortia.

Five-point Likert scales were used: 1 for "totally disagree", 2 for "disagree", 3 for "partially agree", 4 for "agree" and 5 for "totally agree". For each question, a space was included for participants to expand, comment and justify their answers.

The software IBM SPSS 19 was used for quantitative data analysis. Descriptive statistics were performed to characterize the sample. Besides this, further analysis was conducted to analyse the answers. Mann-Whitney $U$ and Kruskal-Wallis tests were run in SPSS in order to test for differences in opinions between groups of respondents. Kruskal-Wallis was used to test for differences in the answers provided according to the following independent variables, which were all coded as either categorical or ordinal variables: number of hotel rooms; number of workers; key market segment; hotel category (number of stars). For the following variables, MannWhitney $U$ was used instead: current belonging to consortium; previous belonging to consortium; number of stars (four and five); affiliation.

Given that many respondents left comments with important insights, these are the main focus of this article. Thematic analysis was performed in order to analyze these 
comments left by the respondents. Thematic analysis is a method for identifying, analysing and reporting patterns in qualitative data (Braun \& Clarke, 2006; Clarke \& Braun, 2013). Themes are patterns of meaning within the dataset, which are developed after reducing the data into codes (Braun \& Clarke, 2006). Diagrams with the main themes arrived at are presented in the results section.

\section{MAIN RESULTS}

Analysis of results begins with a brief characterization of the sample, followed by a quantitative and qualitative analysis of hotel managers' perceptions of the future of hotel consortia.

\section{1) THE SAMPLE}

Four-star hotels correspond to $73.4 \%$ of the sample. Concerning the geographical distribution of the respondents, most were concentrated in Lisbon (26.4\%), followed by Faro (15.3\%) and Porto (10.7\%).

As shown in Table 2, more than $30 \%$ of the hotels have less than 50 rooms, and only $12.4 \%$ have more than 200 rooms. More than half of these hotels have less than 40 employees, and the majority count between 21 and 40 employees (Table 2).

\begin{tabular}{|c|c|}
\hline Number of employees & \\
\hline $0-20$ & $20 \%$ \\
\hline $21-40$ & $32 \%$ \\
\hline $41-60$ & $21 \%$ \\
\hline$>60$ & $27 \%$ \\
\hline Number of hotel rooms & \\
\hline $0-50$ & $31 \%$ \\
\hline $51-100$ & $29 \%$ \\
\hline $101-200$ & $28 \%$ \\
\hline$>200$ & $12 \%$ \\
\hline Location & \\
\hline Urban & $42 \%$ \\
\hline Sea & $22 \%$ \\
\hline Rural & $19 \%$ \\
\hline Mountain & $8 \%$ \\
\hline Other & $9 \%$ \\
\hline Main market segment & \\
\hline Family & $27 \%$ \\
\hline Luxury & $25 \%$ \\
\hline Corporate & $14 \%$ \\
\hline
\end{tabular}




\begin{tabular}{|c|c|}
\hline Romantic & $9 \%$ \\
\hline All-inclusive & $6 \%$ \\
\hline Other & $19 \%$ \\
\hline Affiliation & \\
\hline Independent & $42 \%$ \\
\hline National chain & $38 \%$ \\
\hline International chain & $16 \%$ \\
\hline Marketing consortium & $4 \%$ \\
\hline Belonging to consortium in the past \\
\hline Yes & $18 \%$ \\
\hline No & $82 \%$ \\
\hline Table 2: Sample characteristics \\
Source: own elaboration
\end{tabular}

Concerning the type of location, most of the hotels self-identified as urban (42\%) or sea hotels $(22 \%)$. The most relevant market segments highlighted by the respondents were family $(27 \%)$, luxury $(25 \%)$, followed by corporate $(14 \%)$ and romantic (9\%) (table 2). More than half of the hotels are integrated in chains, mostly national $(38 \%)$, but also international ones (16\%). A very significant proportion of hotels are independent (42\%) and only $4 \%$ belong to a marketing consortium (Table 2). However, $18 \%$ answered that they had belonged to a consortium in the past.

In the following sections, respondents' perspectives about the future of hotel marketing consortia are analysed.

\section{2) LIKELIHOOD OF HOTELS BELONGING TO NETWORKS IN THE FUTURE}

Respondents were asked to rate their level of agreement with the sentence It is likely that, in the future, all hotels will be grouped together in networks. Most respondents chose the option 'partially agree' (Table 3). Answers are distributed among the remaining scale levels in a way that reveals no tendency either towards agreement or disagreement with the statement.

\begin{tabular}{|l|c|}
\hline \multicolumn{1}{|c|}{ Agreement with the first statement } & Percentage \\
\hline 5 - Totally agree & $13 \%$ \\
\hline $4-$ Agree & $22 \%$ \\
\hline 3 - Partially agree & $32 \%$ \\
\hline 2 - Disagree & $21 \%$ \\
\hline - Totally disagree & $12 \%$ \\
\hline
\end{tabular}

Table 3: Respondents' agreement with the statement 'It is likely that all hotels will be grouped together in networks in the future'

Source: own elaboration 
Concerning quantitative analysis, Kruskal-Wallis $\mathrm{H}$ and Mann-Whitney $\mathrm{U}$ tests only revealed significant differences in this answer in relation to the variable 'Affiliation' $(p=0.01)$. More than half of the hotels in the sample were affiliated $(58 \%)$, i.e. not independent, both in the whole sample and in the sample of respondents who answered this question. Hence, the respondents from affiliated hotels were considerably more likely to 'agree' or 'totally agree' with the statement $(41 \%)$, as compared to non-affiliated hotels $(9 \%)$, while being less likely to either 'disagree' or 'totally disagree' $(5 \%)$, as opposed to non-affiliated hotels $(15 \%)$.

Most respondents from non-affiliated hotels tended to only partially agree with the statement $(17 \%)$, while the most common answer for those in affiliated hotels was 'agree' $(27 \%)$. This reveals that those respondents from affiliated hotels are more likely to believe that networks will be crucial in the future.

Concerning the qualitative thematic analysis of comments, it revealed a division in opinions in relation to statement one. The theme with the most occurrences was creation of synergies (44 references, only mentioned by respondents whose answers ranged between partially agree and totally agree). The second most important theme is the strength of independent hotels (23 references, only mentioned by respondents whose answers ranged between partially agree and totally disagree), followed by a similar number of respondents (21 references) who stated that it depends on the characteristics of the hotel (theme mostly mentioned by respondents who only partially agreed). Themes are reported in Figure 1. 


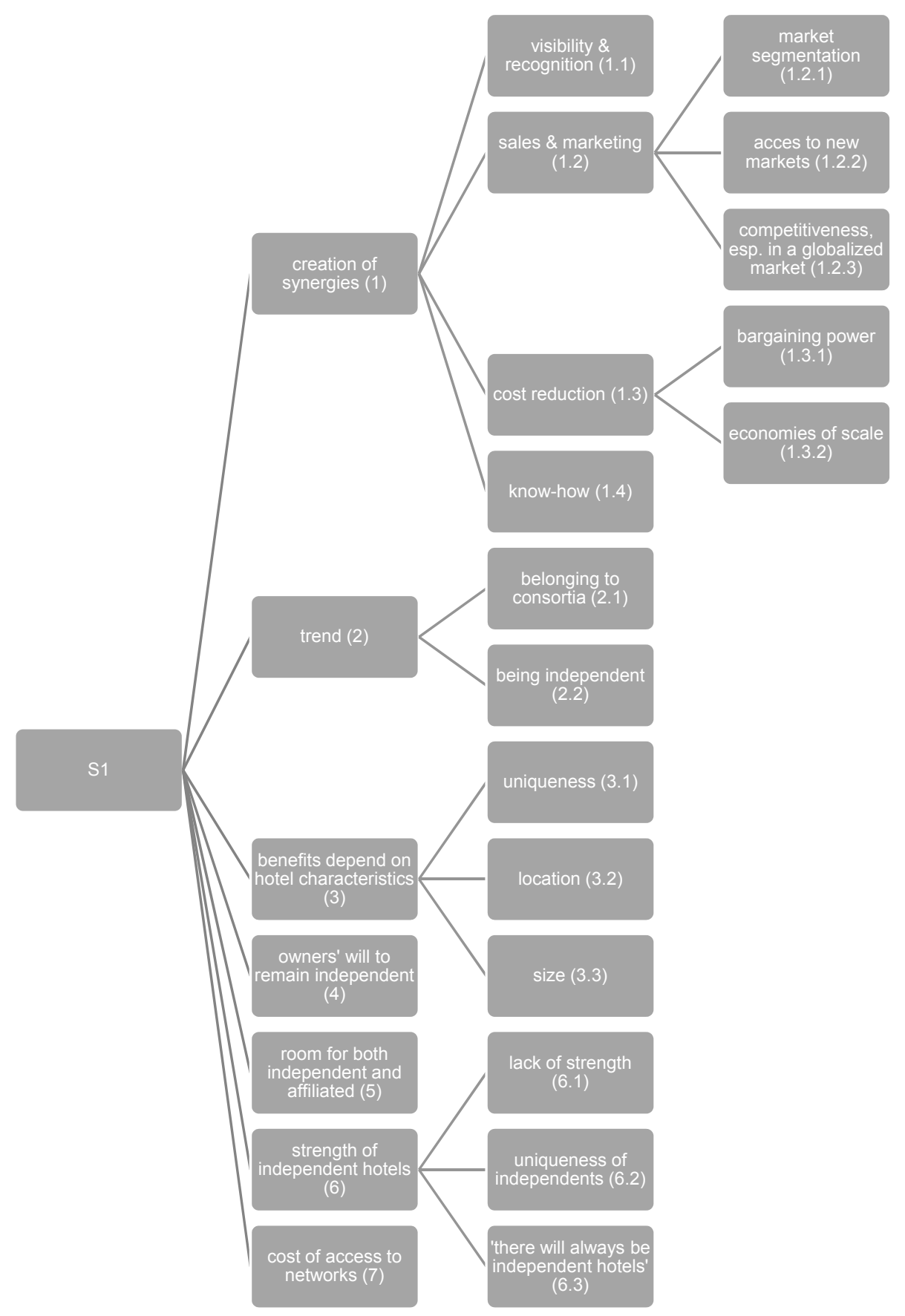

Figure 1: Analysis of comments to Statement 1 (S1): Themes and subthemes Source: own elaboration

First, comments which express agreement with the statement are analysed. Creation of synergies (1) through the integration in networks was the main theme for those who agreed with the statement. Forty-one per cent of comments were related with this theme. Within this theme, the most frequent subthemes were visibility and recognition (1.1), sales and marketing (1.2), and cost reduction (1.3), which 
correspond to the main benefits of networks identified in the literature review (Scott et al., 2008).

A significant percentage of respondents pointed out the synergetic benefits of networks for visibility and recognition (1.1), which lead to greater sales, competitiveness and market penetration. One respondent explained the importance of networks for visibility by stating that 'the customer's decision is increasingly a result of the recognition and trust in the brands'. Hence, some respondents highlighted the importance of networks for the creation of synergies specifically in sales and marketing (1.2) ('more synergies in terms of sales and marketing'; 'synergies and potential advantages in terms of sales and disintermediation'). Some respondents highlighted that affiliation helps in market segmentation (1.2.1), particularly 'for a better definition of each target market' or for 'a better segmentation of the market'. Others emphasized the advantages of affiliation for gaining access to new markets (1.2.2), since 'our products can more easily reach markets they would be unlikely to reach otherwise'. Other respondents still cite the competitive advantages that consortia can offer, particularly in a globalized market (1.2.3), in line with the findings of Holverson et al. (2010):

"This way it will be easier to withstand the fusions of large international hotel chains and to withstand the setbacks in the market and the challenges of change."

"The increase of competition at the global level dictates the need to affiliate in order to obtain greater synergies in terms of costs, improve visibility, increase know-how and increase sales potential through cross-selling, crossing new segments and new geographical markets".

For $11 \%$ of respondents, cost reductions (1.3) are the main reason why hotels will become affiliated in the future (1.3). They believe that such cost reductions can be achieved due to 'the sales synergies generated', and also due to the 'sharing of costs', greater 'cost efficiency' which can lead to a 'decrease [of] image costs', among other costs. Others emphasize that such cost reductions will be the result of an increase in bargaining power (1.3.1), 'both in sales and in purchases' and in the 'acquisition of goods and services'. Other respondents highlight the creation of economies of scale (1.3.2) as the main advantage of networks: 
"The current market demands scale economies in order to increase efficiency and the capacity to attract tourists."

"To explore synergies and obtain economy scales, to benefit from the brands and thus improve the reputation and visibility in a market that is increasingly competitive".

Prior research has amply highlighted the advantages of networking and consortia, particularly the benefits derived from scale economies by integrated hotel chains in comparison to small independent businesses (Dundjerovic, 1999). Cost reduction of promotion and distribution channels in international markets is among the most important benefits brought by adopting and participating in a network-based business model (Holverson \& Revaz, 2006; Ingram \& Baum, 1997).

Although most of the synergic advantages pointed out were related with sales, marketing and cost advantages, the increase in know-how (1.4) was mentioned by a few participants. One of them justified his agreement with the statement by stating that networks can be 'a way of acquiring know-how in hotel management, by following the best practices and current trends in the hotel business'. However, one participant mentioned that although networks may increase businesses' know-how, they do not 'work miracles', since many hotel units do not make use of the tools provided by the brand due to a lack of qualified personnel.

There are also some respondents who, despite mentioning that networks allow for the creation of important synergies, also highlight that hotels should not lose what makes them unique:

"Nowadays business synergies are crucial so that hotels can develop. It allows for the improvement of several economic indicators and reputation. However, it is crucial not to lose authenticity and what makes each unit different."

Only $2 \%$ of respondents justified their agreement with the statement by pointing out that independent hotels lack commercial strength (6.1) ('independent hotels have less and less commercial strength'; 'it's increasingly harder for independent hotels to compete in the market').

For $12 \%$ of respondents, the integration in networks is a trend (2.1). Hence, these respondents justify their agreement with the statement by stating that it is 'a 
tendency for generic hotels', or for 'independent hotels', for whom 'it will always be harder [...] to be truly sustainable'. Another respondent states that 'the trend for independent hotels is to unite and be managed by those who have the know-how in the field'.

As previously mentioned, many respondents are divided, since almost a third of them only partially agreed with the statement. For $16 \%$ of respondents, the benefit of belonging to a network depends on the characteristics of the hotel (3). Most of these respondents either partially agreed or disagreed with the statement. Hence, according to them, while networks might be the future for some hotels, they will probably not be the future for all kinds of hotels. For some, it depends on the ability of each hotel to differentiate itself, either for its uniqueness (3.1) or its location (3.2):

"It depends on the location and the concept of the hotel."

"It depends on their target segments and markets. There are independent hotels which can position themselves well in the market because of the brand they created, their location or their unique concept."

"Hotels in networks share synergies from which they obtain advantages. However, there will always be independent hotels who will want to maintain their total independence and their differentiated position in the market."

For other respondents, it also depends on hotel size (3.3):

"It might be profitable for medium-sized unit, but not for small or micro-sized units."

"It partially depends on the hotel size, not all hotels are interesting for groups."

Other themes associated with only partial levels of agreement with the statement are the idea that some owners will rather remain independent (4), or that there will be room both for independent and affiliated hotels in the future (5), and thus there are doubts that all hotels will be grouped in networks in the future. The first of these themes only gathers $3 \%$ of the responses. These respondents believe that some owners will rather remain independent (4) because they want to maintain the identity of their unit. One respondent added that 'Every owner wants to keep some control in order to maintain the vision that they have defined for the hotel'. As to theme (5), it is mentioned by $5 \%$ of the respondents, who highlight that 'there will always be room 
for different kinds of operation', and thus 'there will always be a mix' of independent and affiliated hotels, because, as justified by one respondent, 'customers look for both of these realities'.

The strength of independent hotels and family management was one of the categories with the most occurrences ( $21 \%$ of responses). With two exceptions, all respondents who mentioned it totally disagreed, disagreed or only partially agreed with the statement. For them, the main strength of independent hotels is their ability to provide unique experiences (6.2) to their guests:

"Independent hotels will always be more unique, as compared to hotels in networks, which share the same characteristics, as well as strategic and communication approaches."

"Independent units bring originality, while chains replicate everything the same way."

"The market looks more and more for unique experiences and places."

"Network synergies can bring benefits, but the difference of each hotel units leads to different experiences, and that is what clients are looking for. Different and unique hotels. Networks tend to be very similar. (...) Networks have many standards, which may collide with the individual characteristics and authenticity of an establishment."

One respondent also added that those networks which allow hotels to maintain their identity and distinctive aspects will have more chances of success. Some believed that there will always be independent hotels (6.3):

"There will always be independent hotels, especially due to the size and sales strategy."

"The market will always demand independent hotels."

"There will always be niche markets and family units."

A few respondents (4\%) even highlighted that the current trend is for hotels to be independent (2.2). All of them totally disagreed with the statement:

"The market for independent hotels has been growing, mostly in the urban 
centers of large cities (i.e. Paris)."

"The market trends go in the opposite direction, there are even hotel chains that opt for a strong division of their properties in 'sub-brands', and that aim to target market niches that chains cannot reach both because of their generic service and strategic positioning."

"Customers value more and more charismatic independent units with their own identity. This makes for a different and unique experience in the destinations they visit."

"There has been a growth in independent businesses, due to their short size it is not worth it integrating them in chains or international brands."

"Nowadays, the greatest hotel chain brands are losing it for independent charm hotels, where management and customer service are not easily replicated by those brands."

Finally, one respondent who disagreed mentioned the cost of access to networks (7) as a barrier for integration, since 'the cost of affiliation is unsustainable for most units'. There were also some respondents whose answers revealed a lack of understanding of what a hotel network or consortium is.

Findings from thematic analysis suggest that synergy creation is perceived as an important benefit of a network-based business model. In fact, synergy creation has been considered by prior research as an important driver of competitiveness adopting the network-based model (Scott \& Cooper, 2007). The fact that almost a half of the participants pointed out this aspect reveals that they are aware of this potential advantage of networks. This also suggests that some of these managers may contribute to stimulate, in the business environment, the making of decisions leading to the enlargement of networks.

Prior research has amply highlighted the advantages of networking and consortia, particularly the benefits derived from scale economies by integrated hotel chains in comparison to small independent businesses (Dundjerovic, 1999). Cost reduction of promotion and distribution channels in international markets is among the most important benefits brought by adopting and participating in a network-based business model (Holverson \& Revaz, 2006; Ingram \& Baum, 1997). Many 
participants in this study revealed their awareness of this advantage of networks.

However, the findings also reveal that many hotel managers are not yet truly knowledgeable about networking and network benefits. Many still display reluctance to adopting a network-based business model. This lack of sensitivity to these new business models may compromise the competitiveness and sustainability objectives of the hotel sector (Tsai et al., 2009).

Unlike what many of the comments suggest, integrating a network does not imply losing 'uniqueness', which was the main argument against networks identified by participants. In fact, many network-based models, such as consortia, do not imply standardization or loss of unique and special characteristics, but are rather focused on the creation of synergies in areas such as sales, purchases or distribution. Therefore, raising hotel managers' awareness of what integration in a consortium implies is crucial, not only for the growth of consortia, but also for the growth of survival of independent units in an increasingly competitive and global market.

\section{3) GROWTH OF ONLINE DISTRIBUTION AND EMERGENCE OF MARKETING CONSORTIA}

The second research question shows completely different results. More than half of the sample $(72.1 \%)$ believes online distribution will favour the development of consortia (Table 4). This is a positive finding, as managers seem to be aligned with the view that digital technologies will affect the performance of single businesses and the whole tourism system (Law, Buhalis \& Cobanoglu, 2014). Only a small percentage disagreed with the statement (7.3\%). Kruskal-Wallis and Mann-Whitney $\mathrm{U}$ tests revealed no differences between the groups analysed.

\begin{tabular}{|l|c|}
\hline \multicolumn{1}{|c|}{ Agreement with the second statement } & Percentage \\
\hline Totally agree & $25.6 \%$ \\
\hline Agree & $46.5 \%$ \\
\hline Partially agree & $20.5 \%$ \\
\hline Disagree & $5.5 \%$ \\
\hline Totally disagree & $1.9 \%$ \\
\hline
\end{tabular}

Table 4: Respondents' agreement with the statement 'It is likely that the increase in online distribution will motivate the emergence of new marketing consortia'

Source: authors 
The thematic analysis of the second group revealed that the main theme is creating synergies (1), and thus gaining dimension in order to survive. This theme is mentioned by a third of respondents who commented on this statement. All of them either agree or totally agree with the statement. Some of the comments grouped under this theme are quoted below:

"With the growing weight of online sales, positioning in this market will be increasingly harder. This will create opportunities and synergies for those who can guarantee the most visibility in order to increase the sales."

"Due to the costs of online channels both in terms of technological development and advertisement, you need to have scale in order to survive in a market where new sales channels emerge on a daily basis. Not everyone will be able to reach the final customer with return."

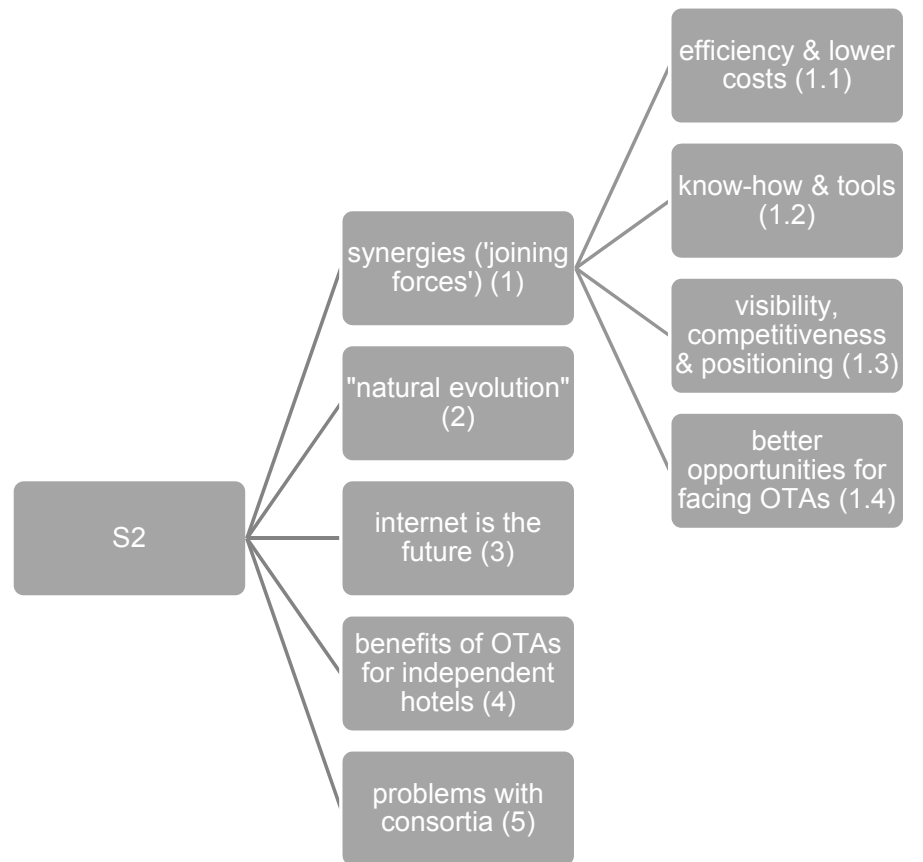

Figure 2: Analysis of comments to Statement 2 (S2): Themes and subthemes Source: own elaboration

Other respondents specify the type of synergies that can be created with marketing consortia, such as attaining greater efficiency and lower costs (1.1). For them, consortia allow for a more efficient management of online sales channels and they 'reduce the costs for small hotels and ease their access to digital business tools'. In fact, the sharing know-how and tools (1.2) was mentioned as a motivation for the emergence of consortia, since there is 'the need for new tools', 'online 
[distribution] demands very specific tools and skills', and 'the costs and know-how are demanding, so it makes sense to join forces'.

Other respondents justify their answers by pointing out the advantages of greater visibility, and hence increased competitiveness and better positioning (1.3):

"Customers increasingly master new technologies and they dare to book their holidays independently. If there is a marketing consortium, everyone wins by increasing their visibility and sharing knowledge. This drives more bookings to these units."

"For sure online distribution will motivate the creation of marketing consortia in order to make it easier to stand out from the competition."

"Competitiveness and penetration in the international market."

Respondents also pointed out that consortia offer better opportunities to face online travel agencies (OTAs) (1.4):

"In order to face the great sharks of online distribution, you need to join forces to have more online weight. Marketing consortia are one way of doing this."

About a fifth of the comments to the statement are related with the impact of online distribution on the emergence of consortia as a trend or a result of the 'natural evolution' of the sector (2):

"It is inevitable in the digital area."

"The dynamics of online promotions and sales demands innovation, which are essential conditions for the emergence of new marketing consortia."

"Because it is natural that we walk towards equilibrium, avoiding the cannibalization of hotels by their partners."

"Online distribution will have to create its positioning and the companies will have to find a way to differentiate themselves from one another. The emergence of new marketing consortia will be a trend, with added-value for the potential affiliates." 
In fact, according to the publication "The Boutique Hotel Report 2019", consortia (or "soft brands") are growing in the United States, both in terms of demand and RevPar.

Nine respondents (12\%), who tended towards agreement, justified their answer by stating that internet will shape the future of hotel distribution (3). For them, 'the future is online' and 'digital is the way forward'. One respondent believes that 'online distribution, coupled with strong digital marketing, will be one of the top trends in the short term'. These respondents did not comment on whether the growth of online distribution will have an impact on the emergence of more consortia. They only expressed their agreement with the idea that online distribution will grow in the future, and that online distribution and marketing will become increasingly important.

As to the respondents who either 'disagreed' or 'totally disagreed', the majority mentioned the benefits of OTAs for independent hotels (4) (10\%):

"With online distribution it is easier for a hotel to operate."

"Online distribution allows independent hotels to place themselves in the market on the same footing as chain hotels."

"Online distribution has increased the visibility for independent hotels and small groups."

"Online distribution is taking away room from marketing consortia, since it gives hotels the opportunity to create a direct communication channel with the market."

"I don't believe so, because OTAs have somewhat assumed that role concerning distribution, which did not exist in the past and which was the key factor for hotel affiliation."

Those statements are in line with Kaynama \& Black (2000), who argued that with the exception of websites like Flifo, which are straightforward reservation systems, online travel agencies provided information on discounts, travel destinations, directions, currency, etc. Law et al (2015) conducted a research in Hong Kong with ten managers of three traditional travel agencies and 11 hotel managers. Results reveal a positive signal concerning industry practitioners who are already aware of 
the trend toward disintermediation and are actively coping with the changes. The increasing use of Internet applications inevitably means that more consumers will make online bookings. One focus group showed that their online exposure and visibility are high because of online travel agency. The three hotels distribute rooms using approximately ten OTAs, including Bookings.com, Expedia.com, Agoda.com and Travelocity.com.

Raguseo et al. (2017) referred in their research in Italy that managing multiple agreements with OTAs allow hotels to reduce vulnerability to OTAs' unilateral renegotiation of their commission fees or may also allow them to have a broader and more focalized market presence, considering the geographical focalization that some of the OTAs have. Hence, we verify that in our study many hotel managers do not agree with the existence of a relation between the emergence of new consortia and the increase in online distribution. They believe in the influence of online travel agencies, which is confirmed by the Vučetić (2009) research work.

Two respondents mentioned problems related with the integration in consortia (5), such as the lack of understanding among members. Another respondent points out that they believe there are only very few consortia who truly contribute with added value, e.g. more revenue.

The findings suggest that, according to the hotel managers interviewed, online distribution will stimulate the growth of marketing consortia. Synergy is one of the most important benefits of consortia, not only according to research participants, but also as seen in the literature. The bargaining power of marketing consortia to negotiate with digital stakeholders is one of these synergetic benefits. Due to the pervasiveness of information and communication technologies (ICT), online distribution is crucial for incrementing sales. This is exactly one of the benefits of belonging to a marketing consortium (Carroll \& Siguaw, 2003), even with the massive entrance of new digital players.

Several respondents recognize the importance of consortia for standing out from the competition, particularly in a context where the costs of online channels are increasing, and OTAs are hindering the positioning of independent hotels. However, many comments revealed a lack of awareness of the benefits provided by consortia. For example, some respondents disagreed by stating the benefits of OTAs for independent hotels, while studies have revealed that hotels have very little 
bargaining power with OTAs (Zhang et al., 2015). This aspect deserves further examination.

\section{CONCLUSIONS}

While most respondents were divided in relation to the likelihood of all hotels being grouped in networks in the future, affiliated hotels were considerably more likely to agree with the statement that networks will continue to be adequate arrangements for hotel businesses. This suggests that affiliated hotels may perceive consortia as being of value for their business (Dundjerovic, 1999), and thus consider it to be the future for independent hotels in general.

One of the results of this study shows that hotel decision makers are not unanimous about the future of the hotel business in network based. One possible interpretation is while many hotel managers recognize the benefits of networks, some related with concerns are still concerned about losing their unit's independence, autonomy and uniqueness. Several respondents believed that one of the main disadvantages of networks was the loss of uniqueness and standardization for small hotels. Besides, many respondents revealed not being aware of the lack of bargaining power that small independent units face when dealing with OTAs. These findings suggest that it is important to raise the awareness of these players that there are network-based models, such as marketing consortia, which enable synergies among its members and greater bargaining power, while not imply standardization or loss of uniqueness.

Therefore, consortia need to improve their communication with small independent units, if they aim to target these players. This study suggests that networks which allow hotels to maintain their identity and distinctive aspects have more chances of success in attracting new members, since the greatest concern of reluctant hotel managers was to lose their independence and autonomy.

Hotel marketing consortia are impressive networking structures that function and strive for survival as living organisms do, and thus can be interpreted through the views of Darwin's cooperation and Porter's competition. Additionally, these consortia operate as effective communication and distribution channels by representing its members around the world. As we currently discuss the impact of new technologies 
on social life and the value of networking, consortia respond to the current global environment by offering members platforms and software that cannot be accessed as working independently in the market. Moreover, consortia also generate economies of scale and contribute to a decrease of opportunity costs, benefits which are accessible only to those participating in these functional networks.

In a sector where competitiveness grows everyday compelled by new technologies, a managerial contribution of this study is the fact that this study it helps consortia decision-makers know hotel managers' perceptions and thus adapt their marketing strategy accordingly. Another managerial contribution is for international hotel marketing consortia which want to be willing to invest in the Portuguese market and findings of this research could be particularly helpful, since it provides insights into Portuguese hotel managers' perspectives on networks and consortia. Hence, the practical implications of this work include raising the awareness of hotel marketing consortia in terms of the views that hotel managers hold of these types of arrangements, and thus improve their communication and marketing approach with hotel managers.

Including, to understand the perceptions of hotel managers about being part of hotel networks. In terms of theoretical contributions, this study sheds light on the is the need of studying more perceptions and believes of the principal players of hotel market hotel decision makers concerning networks and consortia. The qualitative approach used, which is innovative in this field of study, unveiled the different perspectives held by hotel managers, thus adding relevant knowledge to the body of literature. In particular, the erroneous perceptions about consortia and lack of autonomy deserve further investigation.

\section{1) RESEARCH LIMITATIONS}

One of the limitations of this study is the sample. To extrapolate these results to other contexts, a similar study is recommended to be replicated to other countries and other hotel categories. Another limitation is that not all respondents left comments on the statements. Besides, the use of open-ended questions does not allow for an in-depth analysis of respondents' opinions, as would be the case with 
interviews. However, the advantage of the questionnaire is that it was possible to include more participants in the study.

\section{2) SUGGESTIONS FOR FUTURE RESEARCH}

Concerning future research, a deeper investigation should be carried out with this topic considering emergent hotel categories. In the 1960 and 1970s, the tourism industry was dominated by the mass market, and other types of accommodation have emerged. In response, the 4- and 5-star hotels quickly grew and gained importance, offering a unique service according to individual guests' needs. In turn, the 2- and 3-star hotels became associated with the masses and lack of service quality. This reality has now been changing, and the 2- and 3-star hotel chains have been revived and are proliferating with good value for money. Furthermore, these hotel chains are becoming more competitive in the sector and trying to capture new niche segments. The practical implications of this work include raising the awareness of hotel marketing consortia in terms of the views that hotel managers hold of these types of arrangements, and thus improve their communication/ marketing/ approach with hotel managers.

Future research could also investigate the comparative advantages and disadvantages of consortia as compared to OTAs for small-sized independent hotels, as well as investigate which characteristics of consortia are more likely to bring value according to hotel business size. It is also important to better understand the motivation for affiliated hotels to be in a marketing consortium, the factors that influence their choice of a specific consortium, and the reasons which could lead them to abandon them.

\section{References}

Almeida, S. O fenómeno da coopetição nas redes de hotéis - o caso dos consórcios de marketing hoteleiro. (PhD Dissertation, 2018). Available at: https://repositorio.ul.pt/handle/10451/34415 [accessed 20 February 2020].

Almeida, S.; Costa, C.; Simões, J. A cooperação em rede como fator de 
alavancagem na hotelaria. Revista Turismo \& Desenvolvimento, Vol. 21, No 4, 2014, pp. 251-260.

Attila, A.T. The impact of the hotel industry on the competitiveness of tourism destinations in Hungary. Journal of Competitiveness, Vol. 8, No 4, 2016, pp. 85-104.

Ayazlar, G. Entry modes: marketing consortium. In: M. Ivanova; S. Ivanov; V. Magnini (Eds.). The Routledge handbook of hotel chain management. London: Routledge, 2016, pp. 171-184.

Baggio, R. Network science and tourism-the state of the art. Tourism Review, Vol. 72, No 1, 2017, pp. 120-131.

Baggio, R.; Cooper, C. Knowledge management and transfer in tourism: an Italian case. IASK Advances in Tourism Research (ATR2008). Aveiro, Portugal, 2008, pp. 26-28.

Blythe, J. Essentials of marketing. Edinburgh: Pearson Education, 2008.

Bowie, D.; Buttle, F. Hospitality marketing. New York: Taylor \& Francis, 2013.

Brandão, F.; Costa, C. Regional Innovation Systems and Tourism: a Conceptual Approach. Journal of Tourism \& Development, Vol. 17/18, No 2, 2012, pp. 647-660.

Braun, V.; Clarke, V. Using thematic analysis in psychology. Qualitative Research in Psychology, Vol. 3, No 2, 2006, pp.77-101.

Breda, Z. Network relationships and the internationalization of the tourism economy. The case of Portuguese overseas investment in the hotel sector (PhD dissertation, 2010). Available at: https://ria.ua.pt/handle/10773/1856 [accessed 20 February 2020].

Breda, Z.; Costa, R.; Costa, C. Do clusters and networks make small places beautiful? The case of Caramulo (Portugal). In: L. Lazzeretti; C.S. Petrillo (Eds.) Tourism Local Systems and Networking. London: Routledge, 2006, pp. 81-96. 
Buhalis, D. Marketing the competitive destination of the future. Tourism Management, Vol. 21, No 1, 2000, pp. 97-116.

Buhalis, D.; Kaldis, K. eEnabled internet distribution for small and medium sized hotels: the case of Athens. Tourism Recreation Research, Vol. 33, No 1, 2008, pp. 67-81.

Buttle, F. Hotel and food service marketing. London: Cassel Educational, 1986.

Byrne, A. International hotel consortia. In: P. Jones; A. Pizam (Eds.) The International Hospitality Industry: Organizational and Operational Issues. New York: Pitman Publishing/John Wiley \& Sons, 1993, pp. 126-132.

Carroll, B.; Siguaw, J. The evolution of electronic distribution: Effects on hotels and intermediaries. Cornell Hotel and Restaurant Administration Quarterly, Vol. 44, No 4, 2003, pp. 38-50.

Child, J.; Faulkner, D.; Tallman, S.B. Cooperative strategy. Oxford: Oxford University Press, 2005.

Chon, K.S.; Yu, L. The international hospitality business: Management and operations. New York: Routledge, 2012.

Clarke, V.; Braun, V. Teaching thematic analysis: Overcoming challenges and developing strategies for effective learning. The Psychologist, Vol. 26, No 2, 2013, pp. 120-123.

Contractor, N.S.; Wasserman, S.; Faust, K. Testing multitheoretical, multilevel hypotheses about organizational networks: An analytic framework and empirical example. Academy of Management Review, Vol. 31, No 3, 2006, pp. 681-703.

Cooke, P.; Morgan, K. The network paradigm: new departures in corporate and regional development. Environment and Planning D: Society and Space, Vol. 11, No 5, 1993, pp. 543-564. 
Costa, C. Towards the improvement of the efficiency and effectiveness of tourism planning and development at the regional level: planning and networks; the case of Portugal (PhD dissertation). Guildford: University of Surrey, 1996.

Costa, C.; Breda, Z.; Costa, R.; Miguéns, J. The benefits of networks for small and medium sized tourism enterprises. In N. Scott; R. Baggio; C. Cooper (Eds.) Network analysis and tourism: From theory to practice. Clevedon, UK: Channel View Publications, 2008, pp. 96-114.

Cushing, K. Concerns raised over UK long-hours culture. Caterer and Hotelkeeper, Vol. 193, No 4327 (June), 2004, p. 14.

Dundjerovic, A. Consortia: How far can they go towards helping independent Hotels compete with chains? Tourism and Hospitality Research, Vol. 1, No 4, 1999, pp. 370-374.

Fyall, A.; Garrod, B. Tourism marketing: A collaborative approach (Vol. 18). New York, NY: Channel View Publications, 2005.

Gatsinzi, J.; Donaldson, R. Investment challenges in the hotel industry in Kigali, Rwanda: Hotel managers' perspectives. Development Southern Africa, Vol. 27, No 2, 2010, pp. 225-240.

Grängsjö, Y.; Gummesson, E. Hotel networks and social capital in destination marketing. International Journal of Service Industry Management, Vol. 17, No 1, 2006, pp. 58-75.

Hall, C.M.; Williams, A.M.; Lew, A. Tourism: Conceptualizations, disciplinarily, institutions and issues. In: A. Lew; C.M. Hall; A. Williams (Eds.) The Wiley Blackwell companion to tourism. Oxford: Wiley-Blackwell, 2014, pp. 3-24.

Holloway, J.C.; Plant, R.V. Marketing for tourism. London: Pitman, 1998.

Holverson, S.; Revaz, F. Perceptions of European independent hoteliers: Hard and soft branding choices. International Journal of Contemporary Hospitality Management, Vol. 18, No 5, 2006, pp. 398-413. 
Holverson S.; Holverson K; Mungall A.; Centeno A. The strategic importance of affiliations with lifestyle consortium for small and medium-sized independent hotels. Lausanne: École Hôteliere de Lausanne, 2010. Available at: http://m3.ithq.qc.ca/collection/00000022.pdf [accessed 20 February 2020].

Ingram, P.; Baum, J.A. Chain affiliation and the failure of Manhattan hotels, 18981980. Administrative Science Quarterly, Vol. 42, No 1, 1997, pp. 68-102.

Jafari, J. Encyclopedia of tourism. London: Routledge, 2000.

Karl, M.; Reintinger, C. Investigating Tourists' Destination Choices-An Application of Network Analysis. European Journal of Tourism Research, Vol. 15, 2017, pp. 112130.

Kaynama, S.A.; Black, C.I. A proposal to assess the service quality of online travel agencies: an exploratory study. Journal of Professional Services Marketing, Vol. 21, No 1, 2000, pp. 63-88.

Knowles, T. Corporate strategy for hospitality. Harlow, UK: Longman Group Limited, 1996.

Kotler, P.; Bowen J.; Makens J. Marketing for Hospitality and Tourism. New Jersey: Prentice Hall, 1996.

Law, R.; Buhalis, D.; Cobanoglu, C. Progress on information and communication technologies in hospitality and tourism. International Journal of Contemporary Hospitality Management, Vol. 26, No 5, 2014, pp. 727-750.

Law, R.; Leung, R.; Lo, A.; Leung, D.; Fong, L. Distribution channel in hospitality and tourism. International Journal of Contemporary Hospitality Management, Vol. 27, No 3, 2015, pp. 431-452.

Lazer, W.; Layton, R.A. Contemporary hospitality marketing: A service management approach. Orlando, FL: Educational Institute of the American Hotel \& Motel Association, 1999. 
Lee, H.A.; Guillet, B.D.; Law, R. An examination of the relationship between online travel agents and hotels: A case study of Choice Hotels International and Expedia. com. Cornell Hospitality Quarterly, Vol. 54, No 1, 2013, pp. 95-107.

Litteljohn, D.; Foley, M.; Lennon, J. The potential of accommodation consortia in the highlands and islands of Scotland. In: Proceedings of IAHMS Spring Symposium. Leeds: Leeds Metropolitan University, 1996, pp. 55-66.

Litteljohn, D. The role of hotel consortia in Great Britain. Service Industries Review, Vol. 2, No 1, 1982, pp. 79-91.

Lynch, P. Networking in the homestay sector. The Services Industries Journal, Vil. 20, No 3, 2000, pp. 95-116.

Lynch, P.; Morrison, A. The role of networks. In: E. Michael (Ed.), Micro-clusters and networks: The growth of tourism. Oxford: Elsevier, 2007, pp. 43-62.

Morrison, A.J. Marketing strategic alliances: The small hotel firm. International Journal of Contemporary Hospitality Management, Vol. 6, No 3, 1994, pp. 25-30.

Morrison, A.; Lynch, P.; Johns, N. International tourism networks. International Journal of Contemporary Hospitality Management, Vol. 16, No 3, 2004, pp. 197-202.

Niewiadomski, P. The globalization of the hotel industry and the variety of emerging capitalisms in Central and Eastern Europe. European Urban and Regional Studies, Vol. 23, No 3, 2016, pp. 267-288.

Niewiadomski, P. Towards an economic-geographical approach to the globalisation of the hotel industry. Tourism Geographies, Vol. 16, No 1, 2014, pp. 48-67.

O'Connor, P.; Frew, A.J. The future of hotel electronic distribution: Expert and industry perspectives. Cornell Hotel and Restaurant Administration Quarterly, Vol. 43, No 3, 2002, pp. 33-45.

Ōmae, K. (Ed.). The evolving global economy: Making sense of the new world order. Harvard: Harvard Business School Press, 1995. 
O'Reilly, T. What is web 2.0: In: H. Donelan; K. Kear; M. Ramage (Eds.) Online Communication and Collaboration: A reader. Abingdon: Routledge, 2005, pp. 225223

Pallant, J. SPSS Survival Manual. Philadelphia: Open University Press, 2003.

Powell, W.W. Neither market nor hierarchy: network forms of an organization. In: B.M. Staw; L.L. Cummings (Eds.) Research in Organizational Behavior, Vol. 12. Greenwich, CT: JAI Press, 1990, pp. 295-336.

Quintas, M.A. Organização e gestão hoteleira. Lisboa: OtelTur, 2006.

Raguseo, E.; Neirotti, P.; Paolucci, E. How small hotels can drive value their way in infomediation. The case of 'Italian hotels vs. OTAs and TripAdvisor'. Information \& Management, Vol. 54, No 6, 2017, pp. 745-756.

Ramayah, T.; Lee, J.W.C.; In, J.B.C. Network collaboration and performance in the tourism sector. Service Business, Vol. 5, No 4, 2011, pp. 411-428.

Roper, A.J. Hotel consortia: strategies and structure; an analysis of the emergence of hotel consortia as transorganisational forms (PhD dissertation). Huddersfield, UK: University of Huddersfield, 1992.

Rowley, G.; Purcell, K. As cooks go, she went: Is labour churn inevitable? International Journal of Hospitality Management, Vol. 20, No 2, 2001, pp.163-185.

Scott, N.; Cooper, C. Network analysis as a research tool for understanding tourism destinations. Oxford: Elsevier, 2007, pp. 199-215.

Scott, N.; Baggio, R.; Cooper, C. Network analysis and tourism: From theory to practice. Clevedon, UK: Channel View Publications, 2008.

Sfandla, C.; Björk, P. Tourism experience network: co-creation of experiences in interactive processes. International Journal of Tourism Research, Vol. 15, No 5, 2013, pp. 495-506. 
Solnet, D.J.; Paulsen, N.; Cooper, C. Decline and turnaround: a literature review and proposed research agenda for the hotel sector. Current Issues in Tourism, Vol. 13, No 2, 2010, pp. 139-159.

Slattery, P.; Roper, A.; Boer, A. Hotel consortia: Their activities, structure and growth. The Service Industries Journal, Vol. 5, No 2, 1985, pp. 192-199.

Tran, M.T.; Jeeva, A.S.; Pourabedin, Z. Social network analysis in tourism services distribution channels. Tourism Management Perspectives, Vol. 18, No April, 2016, pp. 59-67.

Tsai, H.; Song, H.; Wong, K.K. Tourism and hotel competitiveness research. Journal of Travel \& Tourism Marketing, Vol. 26, No 5-6, 2009, pp. 522-546.

Vallen, G.K.; Vallen, J.J. Check-in check-out: Managing hotel operations. Las Vegas: Prentice Hall, 2009.

Vučetić, A.Š. Influence of Travel Agencies on Selective Tourism Development in Montenegro. Selective Tourism, No 4, 2009, pp. 7-20.

Walker, J.R.; Walker, J.T. Introduction to hospitality management. New Jersey: Pearson, 2013, pp.125-133.

Yeoman, I.; McMahon-Beattie, U. Tomorrow's tourist and the information society. Journal of Vacation Marketing, Vol. 12, No 3, 2006, pp. 269-291.

Zhang, L.; Guillet, B.D.; Kucukusta, D. Online Travel Agents-Hotels' Foe or Friend? A Case Study of Mainland China. Journal of China Tourism Research, Vol. 11, No 4, 2015, pp. 349-370.

Article info: Received 10/02/2020. Accepted 24/02/2020. Refereed anonymously. 